\title{
KIRJOITUS
}

HENRIETTA GRÖNLUND

\section{Mitä on kaupunkiteologia?}

Taupunkiteologia tutkii uskontoa kaupungeissa ja uskonnon ja kaupun1 gistumisen vuorovaikutusta. Mitä ihmettä? Onko uskonto erilaista kaupungissa kuin muualla? Eivätkö kaupungit ole pikemminkin syntisiä kuin uskonnollisia paikkoja? Eikö maallistuminen ole jo melkein hävittänyt uskonnon kaupungeista? Olen Suomen ensimmäinen kaupunkiteologian professori, ja kohtaan aika usein tämänkaltaisia kysymyksiä tieteenalaani liittyen. Tässä lyhyessä puheenvuorossa kerron, miten kaupunki, vaikkapa Helsinki, on itse asiassa täynnä uskontoa. Kerron miten uskonto vaikuttaa kaupungin ja kaupunkilaisten elämään, ja millaisia haasteita mutta myös mahdollisuuksia tähän liittyy. Eli miksi kaupunkiteologista tutkimusta tarvitaan.

Ensimmäinen kysymys kuuluu: mitä uskonto on? Jokaisella on tästä tietysti jokin käsitys, mutta uskonnon ilmiökenttä on itse asiassa laajempi kuin välttämättä tulisi ajatelleeksi. Uskonto on tietysti uskontokuntia, organisaatioita ja rakennuksia, rituaaleja ja uskonnon harjoittamista. Tällaista niin sanottua organisoitunuttakin uskontoa kaupungeissa on valtavasti. Esimerkiksi Helsingissä järjestetään viikoittain satoja erilaisia jumalanpalveluksia ja muita uskonnollisia kokoontumisia, joissa rukoillaan, ylistetään tai meditoidaan. Uusia yhteisöjä syntyy, vanhoja hiipuu pois, yhteisöihin liitytään, niistä erotaan ja niiden sisällä syntyy jakolinjoja. Uskontojen kenttä on kaupungeissa dynaaminen ja elävä.

Uskonto on kuitenkin muutakin kuin jumalanpalveluksia ja rukoushetkiä. Uskontotaustaiset organisaatiot toimivat kaupungeissa laajasti myös muilla 
tavoin, erittäin laajasti esimerkiksi auttamistyössä. Muun muassa ruoka-apu on suomalaisissakin kaupungeissa hyvin pitkälti uskontotaustaisten toimijoiden käsissä ja esimerkiksi korona-avussa niiden rooli on ollut monin tavoin keskeinen.

Nämä eri uskontoihin liittyvät uskonnolliset tilaisuudet ja niiden laaja auttamistoiminta eivät nekään vielä ole uskonnon koko kuva. Me uskonnontutkijat tutkimme paljon myös niin sanottua elettyä uskonnollisuutta tai arjen spirituaalisuutta. Tämä arjen spirituaalisuus on ihmisten perimmäisiin kysymyksiin ja uskoon liittyviä pohdintoja, näkemyksiä ja tunteita, ja niihin kiinnittyviä arvoja, tapoja ja toimintaa. Tällaisia arjen spirituaalisia pohdintoja on useimmilla ihmisillä, niilläkin, jotka eivät kuulu mihinkään uskontokuntaan. Osa ihmisistä on vakaumuksellisia ateisteja - maailmankatsomus sekin - mutta paljon yleisempää on, että ihmiset niin sanotusti uskovat johonkin, vaikka eivät aina osaisi tai edes haluaisi sanoittaa tarkasti mihin.

Suurella osalla ihmisistä on uskomuksia jostain korkeammasta voimasta, jonkinlaisesta jatkuvuudesta kuoleman jälkeen ja käsityksiä perimmäisistä arvoista, jotka koetaan jollakin tasolla annetuiksi. Viimeaikaisten tutkimustemme mukaan suomalaisista pitkälti yli 90 prosenttia pystyy esimerkiksi nimeämään asioita, yleensä useita, jotka ovat heille pyhiä. Nämä ihmisten käsitykset heille pyhistä asioista, elämän tarkoituksesta tai olemassaoloon liittyvistä kysymyksistä vaikuttavat yksilöiden elämässä suoremmin tai epäsuoremmin lukemattomiin asioihin. Ne suuntaavat käsityksiä elämästä ja kuolemasta, siitä, mikä on hyvää elämää, mikä on oikein ja mikä värin, miten elämää eletään, ja millaisia valintoja tehdään. Tällaisten näkökulmien myötä arjen spirituaalisuus vaikuttaa myös kaupungeissa, kaikissa niissä pohdinnoissa ja valinnoissa, joita ihmiset katsomustensa pohjalta tekevät perhe-elämässä, työssä, vapaa-ajalla, kulutusvalinnoissa ja niin edelleen.

Eli kaupungeissakin on tällainen - osin näkyvä, monilta osin näkymätön - uskonnollinen tai spirituaalinen ulottuvuus. Ja tällä en tarkoita tietenkään mitään yliluonnollista ulottuvuutta, sellaisiin ei tieteellinen tutkimus ota kantaa. Vaan tämä spirituaalinen ulottuvuus muodostuu ihmisten uskoon ja hengellisyyteen liittyvistä kokemuksista, pohdinnoista ja niihin kiinnittyvistä arvoista ja toiminnasta, joita voimme tutkia.

Nämä näkökulmat tekevät kaupunkiteologiasta tärkeää myös käytännön tasolla: Uskontoon ja katsomusten moninaisuuteen kaupungeissa liittyy haasteita ja mahdollisuuksia, joita tutkimalla ja ymmärtämällä ihmisten elämää 
kaupungeissa voidaan parantaa. Tällaista ymmärrystä kaupunkiteologinen tutkimus tuottaa. Avaan näitä haasteita ja mahdollisuuksia vielä lyhyesti. Ensin haasteet. Elämän syvät kysymykset ja uskonnolliset vakaumukset ovat erityisen herkkiä ja henkilökohtaisia asioita. Niiden piirissä on helppo loukata ja tulla loukatuksi. Uskontoihin liittyy ennakkoluuloja, valtakysymyksiä ja eriarvoisuutta, syrjintää ja pahimmillaan henkistä, hengellistä ja fyysistä väkivaltaa. Nämä riskit voivat konkretisoitua uskonnollisten yhteisöjen sisällä, uskontojen välillä ja uskonnollisten ja uskonnottomien katsomusten välillä.

Yksilö voi esimerkiksi tulla syrjityksi tai kummeksutuksi uskonnollisen vakaumuksensa tai vakaumuksettomuutensa vuoksi. Vakaumuksen näyttäminen voi olla vaikeaa tai siihen voi liittyä pelkoa tai väkivaltaa. Vähemmistöuskontoja edustavat yksilöt tai yhteisöt eivät aina saa tai uskalla näkyä kaupunkitilassa. Uskontoa voidaan ylipäätään pyrkiä siivoamaan näkymättömiin, ja ajaa uskonnotonta kaupunkielämää, mikä taas uhkaa uskonnonvapautta. Vastaavasti voimakas valtauskonto voi dominoida uskonnottomia katsomuksia ja vähemmistöuskontoja. Tämänkaltaiset ilmiöt aiheuttavat alisteista asemaa ja toisaalta, mitä enemmän uskonto on piilotettava tai vaiettava asia, sitä enemmän sen piirissä voi myös tapahtuu asioita, jotka eivät kestä päivänvaloa.

Kansainvälisesti verkottuneissa kaupungeissa - Suomessakin - myös muun maailman uskonnollisuus on osa täkäläisiä kaupunkeja. Maailmanlaajuisesti tarkasteltuna uskonnon merkitys jatkuvasti vain kasvaa: Uskonnolliset liikkeet, vaikutteet ja innovaatiot liikkuvat ihmisvirtojen, lähetystyön ja informaatioverkkojen välityksellä globaalisti. Ja ne keskittyvät nimenomaan kaupunkeihin, globaalien virtausten solmukohtiin, joissa on myös eniten ihmisiä ja erilaisia resursseja monenlaiseen toimintaan. Esimerkiksi fundamentalistiset liikkeet ovat usein nimenomaan urbaaneja liikkeitä.

Uskonto on siis kaupunkien moninaisuudessa potentiaalinen valtakysymys, johon liittyy syrjinnän, kaltoinkohtelun ja vastakkainasettelun riskejä niin yksilöiden kuin yhteisöjen tasoilla. Mutta uskontoon liittyy myös paljon mahdollisuuksia. Uskonnollisten organisaatioiden uskonnollinen työ ja auttamistoiminta tekevät lukemattomille ihmisille elämästä kaupungeissa parempaa ja merkityksellisempää. Elämän perimmäiset merkityksen ja olemassaolon kysymykset ovat osa jokaisen ihmisen elämää ennemmin tai myöhemmin. Kun läheinen kuolee, kun saa lapsen, kun korona tai ilmastonmuutos pelottaa, elämän mysteeri herättää pohdintoja ja tunteita. Uskonnot ja arjen spirituaalisuus ovat näitä ikiaikaisia kysymyksiä ja niiden vastauksia. Ja sellai- 
senaan ne tuovat yksilöiden ja yhteisöjen ja myös kaupunkien elämään tason, joka parhaimmillaan antaa turvaa, syvyyttä ja merkityksellisyyttä.

Tutkimalla ja ymmärtämällä uskontoa kaupunkien moninaisuudessa voimme ymmärtää sekä niitä riskejä että mahdollisuuksia, joita uskonnon ja spirituaalisuuden syvät ja herkät kysymykset tuottavat. Tutkimalla ja ymmärtämällä uskontoa, voimme luoda katsomuksellisesti yhdenvertaista ja turvallista kaupunkia kaikille sen asukkaille. Ja tutkimalla ja ymmärtämällä uskontoa, voimme mahdollistaa ja edistää merkityksellistä ja hyvää kaupunkielämää, jota uskonnon ja spirituaalisuuden syvätaso kaupunkeihin voi tuottaa. Tämän vuoksi uskontoa on syytä tutkia myös kaupungeissa ja muun muassa tätä tekee kaupunkiteologinen tutkimus.

9.9.2020 pidetystä kaupunkiteologian professorin jublaluennosta Helsingin yliopistossa. 